\title{
関節リウマチに対する金療法の経験
}

長崎原爆病院整形外科 三 原 茂 峰 高嶺

\section{On the Gold Therapy for Rheumatoid Arthritis}

By

\author{
S. Mihara, T. Mine and S. Miyasaki \\ Orthopaedic Clinic, Nagasaki Atomic \\ Bomb Hospital.
}

関節リウマチに対し，辰期の諨画的治療が必要であ るこよは，すでに多くの人々により強調されていると ころである．吾々も炤和 37 年 1 月長愉原爆病院整形外 科が開設されると共に, リウマチクリニークを設置し その診療に従事してきたが，現在までに約 80 名のリ ウマチ患者を取扱い，かなりの成果をあげることがで きたと考えている.

治療の一貫として昨年から金療法を実施し約 1 年余 観察することができたので，その 経験について 報告 する.

金療法の対象とした患者は機能障害のつよいものを 主としてえらび，現在まで約 20 例に投与を行なつて きたが，今回は 1 年近く追求することができた 13 名 について検討することとした。

金製剂としてはゾルガナールBを使用し，投与法は 諸家に準じて行なつたが 1 クール $740 \mathrm{mg}$ 程度の使用 量ではリウマチの活動性を完全に阻处せしめることが 困難であつたために，大多数の症例は総量 $1.5 \sim 2 \mathrm{gr}$ 前後に及んでいる. 副作用はかなり高率に発生すると いう報告も見られるが，吾々の症例では搔痒感がもつ とも多く，全症例中 1 過性の屯のを合め 4 例あり， そ の他には口内炎，胃腸障害，蛋白㽷等がそれぞれ 1 名 づつつたにすぎず，重篤な肝降障害や造血器障害・ 発疹等はみられず, 予想外に副作用の発生が少なかつ たことは幸いであつた。

1 年余経過を追求することができた 13 名について, その治療効果を橋本の判定基準（表 1) にしたがつて 採点すると表 2 の如くで，乙机らのうちステロイドか ら離脱できたものが 4 名あり，他の 1 名はリウマチの 活動性をのこしているにあかかわらず, 数力月にわた
表 1 效果判定基準（橋本による）

1. 炎症々候 (赤沈, C. R. P, 今任球增多) の改善

+1
+1

4. 日常生活機能の改善, 臨床症状の改善 +1

以上の各項中增悪があれば $-1$

表 2 治 療 成 樍

+36 名

+22 名

+12 名

$0 \quad 3$ 名

增 悪な な

計 13 名

ステロイドから離脱出来たもの 4 名

り血清反応が陰性化している．又金療法によつて増悪 の傾向を示した症例は現在までのよころ1名もなかつ た. また症例によつては比較的早期から自覚症状の奵 転を泝えるむのがあつたととは甚だ眮味深い。

再発については橋本はその豊富な経験から $20 \%$ は 半年以内に, $50 \%$ は 1 年以内, $80 \%$ 年以内にみ られるとのべているが，金療法の灵施方法について一 層の工夫改䪪が試みられてよいのではないかと思わ れる.

次に 2,3 の症例について検行を吅えてみたい. 症例 144 才, 우, 看滺婦（罒1)

昭和38年 1 月頃左手関節痛を初発として，足関節・ 滕関節・指関節等に及ぶ. 某内科でステロイド内服老 中心に加療中であつたが, 症状増悪の傾向がみられた ので当科に紹介さ机た。 


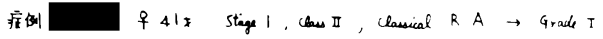

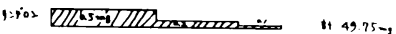

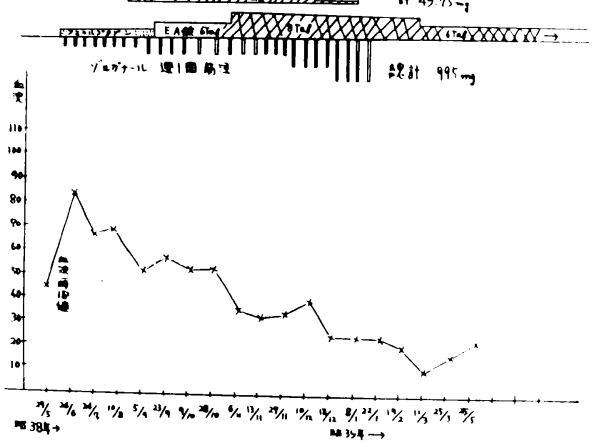

図 1

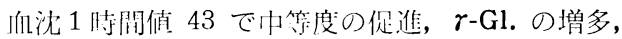
$\mathrm{A} / \mathrm{G}$ 比の低下筞がみら㧈万が, CRP (一), 由血球增 多はみら机なかつた. Stage I, Class II, Classical R. A.

はじめフェニールブタゾン，ついでアスピリン投与 を行なうと共に金療法を開始した，又中途からステロ イドの内服を併用し経過を観察した。 金量の増加につ 机, 自他覚的症状は著しく改善され，ステロイドから の離脱も可能となつたので,ゾルガナール総計 $995 \mathrm{mg}$ にてウ止した。金中止後 6 力月を経過した現在再発の 傾向なく検㮅成績も良好であり，ほぼ支障なく業務に 復州している．金療法の有效例として報告した.

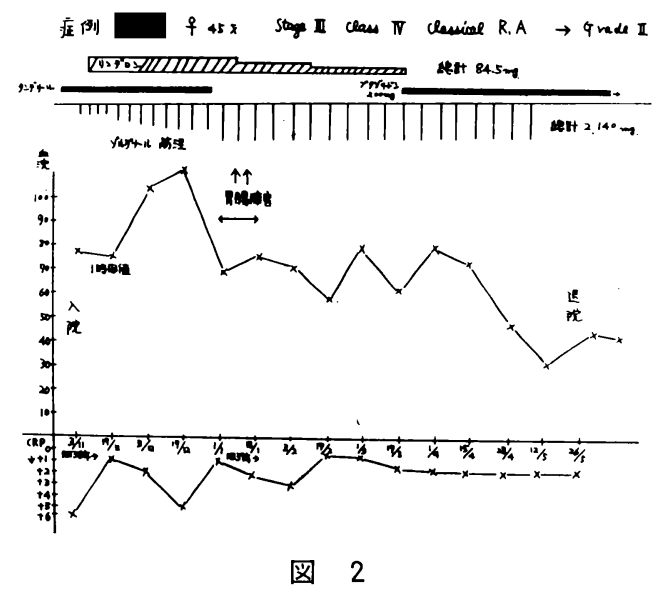

\section{症例 $2 \square 45$ 才, 呆, 家䪞（四 2)}

琞利 30 年発病, 37 尔: 8 月より約 3 力月間当科リウ アチ外来に闻䇠したが, 経济上の理由から治療を中絶
していた. その後症状増悪したため某医に入院し, 数 カ月間ステロイド内服を中心に加療したが体動全く困 難となり，かつ満月様顔貌を呈するようになつたため に当科に収容された。

初暗時血沈 1 時閒值 78, CRP $(6+)$. Stage III, Class IV, Classical R. A.

金製剂の投与と共にステロイド，フェニールブタゾ ンの内服を併用した．入院後約 3 力月を経過した顷，

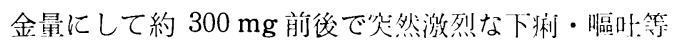
の䍙晹症状が約 2 週間つづいた. 内科的検索によつて あ原因は全く不明であつたために金癔法は中忖するこ となく継続し，かたわら肝被䍀剂の投与，P.Z.C の 静注などをつづけて漱やく症状は消退した.しかし, この後は経過贲だ順調でゾルガナール B 1,100 mg 前 後でステロイドからの離脱も可能となり，総け 2,140 mg にて中した。㠷後はブタゾリジン $200 \mathrm{mg}$ の みにて維持可能の状態となつたために非院，現在外来 にて钼察中であるが良好な経過をたどつている.

治療経過中の下痢・嘔叶等の界晹障雪は金製剂の副 作用と考えられるのでその参考例として報告した。

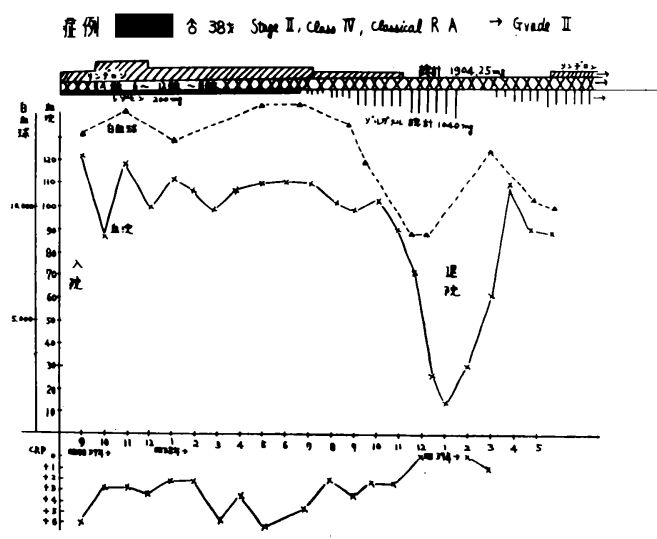

図 3

\section{症例 $3 \square 38$ 才, 今, 工員 (図 3)}

昭和 30 年発病，すでに 各医を転々として加療中で あつたが臥床の止むなきに至つたので，37年 9 月当科 に収容された. Stage II, Class IV, Classical R. A. 初晾時血沈 1 時間 121, 白血球 13,050, $\boldsymbol{r}$-Gl. 38.6 $\%, \mathrm{~A} / \mathrm{G}$ 比 0.51 で病勢は甚だ激烈であった。

ステロイドの内服と共にクロロキンの投与を行なつ たが，1年の経過で血沈 1 時間值 100, 白血球 15,000

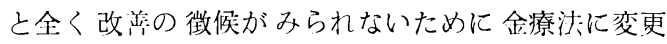


した.

ゾルガナール B 計 $1,040 \mathrm{mg}$ 約 6 力月間の投与-で血 沈值 22 , 白血球 9,900 と著明な改善をみると共にス テロイドからの離脱も可能となつたために, 職場復帰 の目的で退院した. しかし退院後約 3 力月で血沈值の 増悪, Morning stiffness 等を泝える傾问がみられた ので，再びン゙ルガナールB の投与を再開すると共に， ステロイドの少星内服を余儀なくさ机ている有様で ある.

木例は再発例として倹殒した。

以上まだ症例む少数であり，かつ観察期間む 1 作余 の短期間であるために，金療法の效果を結論するこ之 は早計であるとしてあ，関節リウマチに対し決定的な 治療法を欠く現状としては, リウマチ治療の一環とし て甚だ有用な薬剂であるという印象を深くするもので ある。

\section{文献}

1）橋本：リウマチ. 3 巻, 18 頁, 昭 36 .

2）大夙・他：日本医事新報. No. 1794，6頁，昭 33.

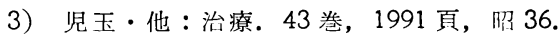

4）伊藤・他：治療. 44 巻, 169 頁, 炤 37.

5）森永・他：綜合臨床, 12 巻, 2129 頁, 昭 38 .

6）矢野・他：臨床リウマチ学 (医学書院), 269, 昭 33 .

\section{犋 問少州厡生年金 橋 木勝之} 私共も関節リウマチ患者については，できるだけ金
療法を併用しているが，初期の投与量を Solganal B, 第 1 回目 $1 / 4$ 量, 第 2 回目 $1 / 2$ 量等之渐次增量して いる. この方法ではあまり副作用はないように思う. 先生のところでは如何がなさつているか，

$$
\text { 答演考 }
$$

Solganal B 1 号週 1 回筋注上り始め, 各号 4 本づ つ計 $740 \mathrm{mg}$ に達する.臨休所見が改潽されない時 は， 4 只 $100 \mathrm{mg}$ 週 1 回筋注を続け，1.5〜2.0 gr を 目標上して投与を続ける. 又症例によつては, $100 \mathrm{mg}$ 前後で著明な自覚症状の改湴をみるものがあるので， この際は，使用中の $\mathrm{mg}$ の注讨を継続する埸合む ある。

質問大熊大 木 村 発表症例は, Gluco corticoid 併用例であるが, Goldのみ, 又は Gold と Sulcylate, Chloroquine の併用で治療した御経験は如何が。

答 演萑

我々のクリニークを酒門した患者は，多くステロイ ド㥜癖に陷つているので，始めからステロイドを奴 て治療を行なうことは困難な場合が多い。したがつ て, ステロイドは最底維持量で併用する. しかし, 入 院患者は極力フェニールブタゾン, アスピリン等のみ でやつていく方法をとつている. それで治療が困難な 場合は，なるべくステロイドの関節内注入を併用して いるが, 实際問題として内服を余儀なくされている埸 合が多い. 